\title{
Duties to Self as Duties to One's Future Self
}

\author{
By Joseph Kranak
}

Presented at the 2019 Great Lakes Philosophy Conference;

Siena Heights University; Adrian, Michigan; April 5, 2019.

That we might have duties not just to others but to ourselves has not been universally accepted in the history of philosophy. Many have rejected the notion for various reasons, but in this paper we'll defend the idea that we do have duties to ourselves. We'll justify it on the grounds that it is a duty to a distinct future self. We'll start by talking about the limitations of other justifications of duties to self and then explain this justification and some of its limitations.

\section{Some Traditional Arguments for Duties to Self}

By saying we have certain duties to ourselves, means there are certain rules that it would be morally wrong to violate entirely insofar as they affect oneself. For example, probably the most discussed, historically, duty to self is the duty not to commit suicide. Suicide can and has been objected to on the grounds that it harms others or the community. ${ }^{1}$ For example, the suicide of a single parent of two small children could at least potentially be condemned on the grounds of neglecting parental duty. However, to say we have a duty to self is to say that it is wrong to commit suicide, neglect one's health, abuse drugs and alcohol, or take excessive personal risks independent of any effect it might have on any other person. ${ }^{2}$

Many of these examples, such as taking care of one's health, can easily be justified, in Kantian terminology, as hypothetical imperatives. For example, we could say that, "If you want to live a happier, healthier, longer life, you ought to take care of your health." But such imperatives are contingent on a person wanting to live a happier, healthier, longer life. The difficulty for justifying duties to oneself is that, if a person doesn't care about such things, then this hypothetical duty wouldn't apply. And if such is the case, how can we leap to asserting the categorical imperative that you ought to (whether you want to or not) take care of your health?

There have been a number of ways duties to self have been defended historically. I'll mention a few. Virtue ethicists usually generally include at least some virtues that concern treatment of self, such as temperance or the Confucian doctrine of the mean (zhongyong). ${ }^{3}$ Others also give consequentialist arguments by arguing that traditional duties to self, such as taking care of one's health, life, and body, will increase net well-being, which has objective

\footnotetext{
${ }^{1}$ Most notably Thomas Aquinas, Summa Theologiae II-II, Q64 A5.

${ }^{2}$ Kant makes a similar point when talking about suicide, "[Killing oneself] can... be regarded as a violation of one's duty to other people (the duty of spouses to each other, of parents to their children, of a subject to his superior or to his fellow citizens, and finally even as a violation of duty to God, as his abandoning the post assigned him in the world without having been called away from it). But since what is in question here is only a violation of duty to oneself, the question is whether, if I set aside all those relations, a human being is still bound to preserve his life simply by virtue of his quality as a person"(Metaphysics of Morals, 6:422, trans. Mary J. Gregor).

3 See the eponymous text "The Doctrine of the Mean" for the central discussion of zhongyong.
} 
value. ${ }^{4}$ Or there are teleological arguments that derive specific duties from purported purposes of our features or our nature, found in Kant and in natural law ethics.

However, I want to focus on two styles of argument that I think most persuasive. First, many philosophers defend duties to self on the grounds that life and the body have unlimited and irreplaceable value. ${ }^{5}$ Immanuel Kant would be a good example of this, with his argument that one ought not to treat oneself as a means ${ }^{6}$ and with his distinction between things with dignity (which have unlimited and incommensurable value) and things with price ${ }^{7}$ (which have limited and commensurable value). ${ }^{8}$ And he often speaks of violations of duties to self as devaluing oneself or one's humanity. ${ }^{9}$ In Classical Chinese philosophy, the Yangists make arguments along these lines, arguing that since body and life are irreplaceable, they exceed in value all replaceable things. ${ }^{10}$ And in the Yangist sections of the Annals of Lü Buwei,${ }^{11}$ the Zhuangzi, ${ }^{12}$ and the Liezi,${ }^{13}$ almost identical points are made about how it's not worth sacrificing one's health or life even to gain power over a whole empire.

A second argument for duties to self is that our life and body are not really ours. Aquinas gives this argument in the Christian tradition, arguing that our life is a gift from God, which we are required to take care of. ${ }^{14}$ But this argument doesn't depend on any theological assumptions. The Yangists, within Chinese tradition, make a similar argument, ${ }^{15}$ and a person could likewise

${ }^{4}$ Diane Jeske, "Perfection, Happiness, and Duties to Self," American Philosophical Quarterly, 33:3 (Jul., 1996), pp. 263-276.

${ }^{5}$ A good contemporary justification of duties to self on the grounds that violating such duties devalues the self is Thomas E. Hill Jr., "Servility and Self-Respect," The Monist, 57:1, Jan 1973, 87-104. Hill notes that duties to self derive from a duty to uphold one's rights and that failure to do so is to devalue oneself, and he believes duties to self (at least servility) cannot be derived from utilitarian considerations (pp 90-91).

6 The Formula of the End in Itself (4:429).

7 4:434.

${ }^{8}$ I am influenced here by Samuel J Kerstein, who interprets Kant's notion of treating oneself as a means as failing to treat oneself "as something that is unconditionally and incomparably valuable"(p. 204; Samuel J. Kerstein, “Treating Oneself Merely as a Means," Kant's Ethics of Virtue, Ed. Monika Betzler [New York: de Gruyter, 2008], pp. 201-218). And Lara Denis offers a similar reading, saying that a maxim is impermissible (creating a perfect duty) if willing the maxim, "expresses disrespect for the dignity of one's rational nature" and a maxim is an imperfect duty if pursuing the maxim, "constitutes a commitment to strive to realize one's rational nature"(p. 327; Lara Denis, "Kant's Ethics and Duties to Oneself," Pacific Philosophical Quarterly, 78:4, Dec 1997, pp 321-348).

${ }^{9}$ For example, in Metaphysics of Morals, when describing particular duties to self as an animal being (6:421-428), he several times brings up how violating these duties is debasing. And Kant is clear that it is our rationality that gives us dignity. For example, "morality and humanity insofar as it is capable of morality, is that which alone has dignity"(4:435), and, "the will of a rational being, in which, however, the highest and unconditional good alone can be found"(4:401). See also his discussion of nonrational living things, "beings without reason, still have only a relative worth, as means, and are therefore called things"(4:428).

10 Annals of Lu Buwei Book 2, Chapter 2

11 Ibid.

12 Such as the first section of chapter 28.

13 It's well known that the "Yang Chu" section of the Liezi doesn't represent Yangist thought. However, A.C. Graham defends the position that some sections of this chapter and next are from earlier Yangist sources and are distinct from the rest of the chapter (see, The book of Lieh-tzĥu, translated by A. C. Graham, Butler \& Tanner, 1960, p 136). A section on valuing the body above the empire can be found, in Graham's translation, on pp 148-149.

14 Summa Theologiae II-II, Q64 A5. Paul lays out the idea that a person is God's temple in 1 Corinthians 3: 9-17, which has had an influence on many Christian beliefs about duties to self.

${ }^{15}$ For example, the "Yang Chu" chapter of the Liezi says, "my body is not my possession" (p 153 in Graham's translation) and Annals of Lu Buwei Book 1, Chapter 2 says our life is a gift from Heaven.. Note that describing 
make the argument that our life and our body are something we were given by our parents without really have earned or necessarily deserving them. By this, we could reason that my life and body are not fully my own.

\section{Some Objections to These Arguments}

There are objections that could be raised against both arguments. Beginning with the first, the objections differ concerning whether my life, health, body, and general well-being have value either to me and/or to others. So let's first look at duties to self in terms of life's value to others. The implicit argument seems to be:

1) To deprive someone of something of value is to harm the person.

2) Your life and body are of great value to others.

3) Therefore, by shortening your life and body (such as through neglect, excessive risk-taking or suicide), you do great harm to others.

It's the first premise that is the most questionable. It seems plausible only for depriving people of something they have some entitlement to. If I steal my neighbor's car, then I deprive him of something of value and do him wrong. But if I lend him my car and then demand it back, though I still deprive him of something of value, I do him no wrong, unless he had some special entitlement to it for other reasons. ${ }^{16}$ The same seems to apply to my life and body. Unless someone has some special entitlement to it (which may be the case in some special circumstances, like in cases of children who depend on their parents), then I do no person wrong by in any way shortening or risking my life.

Insofar as my life, body, and health are valuable to me, then I set their value. I may find them infinitely valuable, as Kant does, or I might not, or I might find that they are less valuable than other tradeoffs. This comes back to the point made above about hypothetical imperatives, if I don't find my life infinitely valuable, by what criteria can we say I ought to?

Assuming that life has infinite value, in fact, is not all that plausible and leads to absurdities. It leads to the conclusion that I ought to do whatever I can to extend my life, even if it entails great suffering or injury to myself and others. And it leads to the conclusion that I would be better of as a long-lived tree, like a giant sequoia, instead of a human, despite that I would miss out on all the richness of human experience. So, if we assume that life has finite value, then we'd need to make the argument that life ought to be given more value than other tradeoffs, such as pleasure, happiness, family, and success, whose pursuit might shorten life. That is, we need to explain why one ought to give life more value or why it's wrong to undervalue it.

Concerning the second argument, the argument is that, if there is something that I use but do not fully own, I have a special obligation to take care of it. Just like if I'm borrowing a car or using a car I share with someone, I ought to be extra careful with it. However, the assumption that my life and body are not fully my own is open to question, primarily because they are both unalienable from me. Unlike a car, no one can use my life and body except me.

these chapters as "Yangist" was defended by A. C. Graham (Disputers of the Tao: Philosophical Argument in Ancient China, Open Court Publishing, 1989, pp 55). Though Chen Qiyou attributed these "Yangist" sections to the Yin-Yang School ("Appendix D: School Affiliations of Individual Chapters According to Chen Qiyou," from The Annals of Lü Buwei: A complete Translation and Study, by John Knoblock \& Jeffrey Riegel, Stanford Univ Press, 200, p 693.) But what particular school these ideas should be attributed to is not important for this paper.

${ }^{16}$ For example, if I made him a promise that he could have it for 30 days but asked for it back in 15 days. 


\section{Traditional Objections to Duties to Self}

It's probably helpful now to look at some of the major objections to duties to self in general. Some philosophers have worried about duties to self on the grounds that they're too demanding. ${ }^{17}$ In other words, when people ordinarily say things like, "You should eat healthy food," or "You should exercise regularly," the "should" is meant not as a moral prescription and extending morality to things like taking care of our physical health or cultivating our skills extends the scope of morality to things too trivial to be morally relevant.

However, though this may be true for some duties to self, it can't apply to all duties to self. Suicide, if nothing else, is certainly not trivial. And Kant also includes our moral perfection as a duty, ${ }^{18}$ including perfecting one's "moral cast of mind," in order to "satisfy all the requirements of duty." 19 In other words, we have a duty to make ourselves the type of person that behaves morally. This hardly seems overly demanding. However, the general point that the scope of morality should extend no further than is necessary is a relevant one that we'll return to.

A second objection is that duties are really a function of a relationship between two individuals. For example, Kurt Baier explains that duties emerge due to a potentially revocable agreement or promise one makes with another. ${ }^{20}$ So, as he says, "A world of Robinson Crusoes has no need for a morality and no use for one." 21 Likewise, Marcus Singer argued that a duty is a right or claim upon another person. ${ }^{22}$ If you owe me money, then I have a claim to your money. If you ought not to kill me, then I have a right not to be killed, but how can I claim to have a right or claim to something from myself? Likewise, you can't make a promise or claim on yourself. John Stuart Mill similarly objects to duties to self on the grounds that duty is like a debt, "It is a part of the notion of Duty... that a person may rightly be compelled to fulfil it. Duty is a thing which may be exacted from a person, as one exacts a debt." ${ }^{23}$ If this analogy is accurate, then it follows that we can't have a duty to ourselves because we can't have a debt to ourselves. ${ }^{24}$

These objections portray morality as analogous to a contract, a view which has many objectors, ${ }^{25}$ but I think what makes these objections intuitively plausible is that one of the main purposes of morality is to prevent conflicts of interest. Just as James Madison had said that, "If men were angels, no government would be necessary," ${ }^{26}$ we might say that if people were

${ }^{17}$ For example,: Bernard Williams, Ethics and the Limits of Philosophy, Cambridge: Harvard University Press, 1985, pp 179-182 and Susan Wolf, "Moral Saints," Journal of Philosophy 791982 419-439

${ }^{18}$ Metaphysics of Morals, 6:387.

${ }^{19}$ Metaphysics of Morals, 6:387.

${ }^{20}$ p 227-28, from: Kurt Baier, The Moral Point of View: A Rational Basis of Ethics, Ithaca: Cornell University Press, 1958.

${ }^{21}$ Baier, p 215,

${ }^{22}$ Marcus Singer explains this in two places: "On Duties to Oneself," Ethics, 69:3 (Apr., 1959), pp. 202-205; and Generalization in Ethics, London: Eyre \& Spottiswoode, 1963, pp 311-318.

${ }^{23}$ John Stuart Mill, Utilitarianism, ch. 5, paragraph 12.

${ }^{24}$ As he explicitly says in On Liberty, ch. 4, paragraph 6: "What are called duties to ourselves are not socially obligatory, unless circumstances render them at the same time duties to others."

${ }^{25}$ For example, Mary Midgley, "Duties Concerning Islands: Of Rights and Obligations," Environmental Ethics, ed. Robert Elliot, Oxford: Oxford University Press, 1995, pp. 89-104. Her main objection is that contracts are between rational agents, but morality extends also to non-rational and not-yet-existing beings, like animals, nature, and future generations.

${ }^{26}$ Federalist no. 51. 
entirely good, no moral rules would be necessary to restrain them. In other words, we are tempted to hurt, take advantage of, and deceive others, but we aren't tempted to do the same to our self.

\section{Temporal Bifurcation}

However, one of the big assumptions underlying these objections to duties to self is that the self is unified across time. ${ }^{27}$ In other words, it's assumed that if I do something that benefits me today but harms me in the future, then the object of both the help and harm are the same. But what if we instead think of the self of the present as different from the self of the future.

This doesn't require us to reject the metaphysical notion of identity across time. This idea of temporally distinct selves can be thought of as a metaphysical fiction used for the sake of deriving duties to self.

The reason why this fiction is justifiable is because we as humans act as if the present self and the future self are distinct selves. As Thomas C. Schelling put it, "People behave sometimes as if they had two selves, one who wants clean lungs and long life and another who adores tobacco, or one who wants a lean body and another who wants dessert." 28 It's the reason, for example, why we procrastinate. The logic of procrastination is basically, "I don't want to do this work, so I'll give it to future me and let him take care of it while I relax." Procrastination seems patently absurd if we think that the interests of our present self are just as important as the interests of our future self. And empirical research has shown that our willingness to help and harm our future self is about equal to our willingness to do the same to others. ${ }^{29}$

The idea of temporal bifurcation is well in line with contemporary ideas of decisionmaking, like time preference and temporal discounting, which both refer to our tendency to value a thing in the future less than the exact same thing now. These ideas are useful in economics to explain why interest is paid on loans (to compensate for the difference in value between money now and in the future). And in psychology, it explains why immediate rewards and punishment are more effective than delayed rewards and punishments.

To understand why temporal bifurcation makes a difference, all we need to do is return to the arguments made above. First, the argument was made that one's health, life, and body is valuable to others, but the premise that "To deprive someone of something of value is to harm the person," was implausible unless the person had some special claim to it. In the case of a future self, however, it's very clear that one's future does have some special claim to the present self's life, health, and body - since the present self's life, health, and body may potentially become the future self's life, health, and body. And the point that one doesn't fully own one's

27 Jeske writes, in reference to Marcus Singer's arguments, "some well-known objections to the notion of a duty to self depend upon a notion of the person as perfectly identical over time"(Jeske 272).

28 Thomas C. Schelling, "The intimate contest for self-command," Choice and Consequence: Perspectives of an Errant Economist, (Harvard University Press, 1984), P 58.

${ }^{29}$ For example: Hal Ersner-Hershfield, G. Elliott Wimmer, and Brian Knutson, "Saving for the future self: Neural measures of future self-continuity predict temporal discounting," Social Cognitive and Affective Neuroscience 4:1, Mar 2009, 85-92; Emily Pronin,Christopher Y. Olivola \& Kathleen A. Kennedy, "Doing Unto Future Selves As You Would Do Unto Others: Psychological Distance and Decision Making," Personality and Social Psychology Bulletin, 34:2, Feb 2008, 224-36; Emily Pronin \& Lee Ross, "Temporal Differences in Trait Self-Ascription: When the Self is Seen as an Other," Journal of Personality and Social Psychology 90:2, Feb 2006, 197-209. I think this is enough to address criticisms such as that future selves are not really distinct or are less distinct that one person from another. For example, Rawls, in his critique of utilitarianism, criticizes this line of thinking (John Rawls, A Theory of Justice: Revised Edition, Belknap Press, 1999, pp 19-27). 
health, body, and life does make more sense if we assume that they are shared between one's present and future selves.

Temporal bifurcation also addresses Singer's point that a duty is some right or claim on another person. From the perspective of temporal bifurcation, the duty is to one's future self, and the future self has a claim on the present self. In addition, if we think of duty as something like a promise or agreement between multiple people, this too can be extended to future selves. A resolution can be thought of as a promise between one's present self and one's future selves.

And it does reasonable that there can be conflicts of interests between one's present selves and future selves that morality is necessary to resolve. For example, my present self might want to be lazy and eat excessive amounts of food, whereas my future self wants to be healthy and fit; this creates a conflict and the possibility of moral reasoning to resolve it. The fact that the present self is making decisions on behalf of the future self creates a principal-agent problem (problems made by people making decisions on behalf of others). The future self is here the principal and the present self the agent. Since there are potentials for different interests between the principal and agent and the future self is powerless to affect decisions, then it makes sense to use ethical constraints to prevent the present self from trampling on the interests of the future self.

So, when does this future self begin? Thinking of the future self as separate raises problems of vagueness - there's no bright line telling me that the self in five minutes is still part of the present but the self after one day is future (since for our purposes, the "present" is not defined as an indivisible point but an indefinite range). Our criteria is that future self is the self far enough in the future that I am prone to neglect its interests.

In fact, it might good to think of this in a contractualist framework: duties to self are ones that all members of the temporally distinguished community of selves would consent to, with most weight given to those most likely to exist (since both the odds that a future self will ever exist declines in inverse proportion to its distance in time from the present and my life expectancy will shrink as I age.) And you can't always favor future selves or you will end up delaying certain benefits indefinitely.

\section{Applications to Particular Moral Questions}

The utility of this approach is also that it justifies different conclusions about duties to self. For example, focusing on suicide, many of the previous theories mentioned - including Kant, natural law, and Yangism - are all unambiguously against suicide, seemingly without exception. ${ }^{30}$ But applying the model of temporally bifurcated selves leads to subtly different conclusion. At first we might think that, since clearly my future self would rather be alive, that it would never consent to my present self committing suicide, but this is clearly wrong.

It's probably true in most cases that suicide would be undesirable to future selves. That is, If I were to attempt to terminate my life and have my attempt interrupted by the interventions of others, I would probably be thankful for the intervention later. But suicide needn't be undesirable to future selves in all cases. If one is facing a death that is imminent and deeply painful, undignified, or generally awful in some way, it seems unlikely that the future self would prefer life than awful death. Similar conclusions would be reached in some cases of euthanasia. If you're suffering from an incurable disease that entails much future suffering, would your

\footnotetext{
${ }^{30}$ Kant is clear in his Lectures on Ethics that suicide is never permissible (27:372).
} 
future self willingly submit to that suffering? So, at least in some cases, prematurely ending a life wouldn't violate the interests of a future self.

Before closing, we should acknowledge that the question of one's moral duties to oneself may be entirely one's own concern. ${ }^{31}$ One motive for opposing the idea of duties to self is to avoid being too critical or intrusive into others' lives. As John Stuart Mill says, "The term duty to oneself, when it means anything more than prudence, means self-respect or self-development; and for none of these is any one accountable to his fellow-creatures, because for none of them is it for the good of mankind that he be held accountable to them." 32 Thus, it's rather up to oneself to criticize oneself for failing in one's duties to self. That is, insofar is one is a member of a community of selves stretching into the past to the day of one's birth and into the future until one's death, then insofar as one's actions do not affect anyone else, it is entirely the concern of that community alone whether one has fulfilled those special duties or not. The reason is because it is only the self and its future or past iterations that can judge which ends, ideals, and interests are important and take precedence.

In the case of suicide this all the more salient. After someone has died by suicide, we don't want to (and probably shouldn't) be speaking ill of the dead by saying they did something wrong. However, we can separate the critical aspect from the duty itself. That is to say, we mostly shouldn't be criticizing others for failing in their duty to self. But the duty still exists.

This leads to the conclusion that that the only person who can judge whether I've violated duties to myself is me. Making decision for my future selves involves tradeoffs, and the question isn't what some outside person might think of these tradeoffs but what my future self would think of these tradeoffs. As mentioned above, we don't want to extend morality to questions that are too trivial, so duties to self should be considered largely a personal issue.

\footnotetext{
${ }^{31}$ Kant appears of a similar opinion, as he admits that it is impossible for me to promote the moral perfection of another (Metaphysics of Morals 6:386; thus, one's moral perfection is each individual's business and responsibility (6:386), and he also makes it a principle of government, "No one can coerce me to be happy in his way (as he thinks of the welfare of other human beings); instead, each may seek his happiness in the way that seems good to him, provided he does not infringe upon that freedom of others to strive for a like end which can coexist with the freedom of everyone in accordance with a possible universal law (i.e., does not infringe upon this right of another)"(8:290). Hill also agrees concerning servility that it is not others role to complain, since "when we say that a duty is to a certain person, we often indicate thereby the person especially entitled to complain in case the duty is not fulfilled"(p 102).

32 On Liberty, ch 4, para 6.
} 